Article

\title{
State Ownership and Risk-Taking Behavior: An Empirical Approach to Get Better Profitability, Investment, and Trading Strategies for Listed Corporates in Vietnam
}

\author{
Tran Thai Ha Nguyen ${ }^{1,2}{ }^{4}$, Massoud Moslehpour ${ }^{1,3}$, Thi Thuy Van $\mathrm{Vo}^{2}$ \\ and Wing-Keung Wong $4,5,6, *$ D \\ 1 Department of Business Administration, Asia University, Taichung 41354, Taiwan; \\ nguyen.tranthaiha@sgu.edu.vn (T.T.H.N.); mm@asia.edu.tw (M.M.) \\ 2 Faculty of Finance and Accounting, Saigon University, Ho Chi Minh City 700000, Vietnam; \\ vothuyvan@sgu.edu.vn \\ 3 Department of Management, California State University, San Bernardino, CA 92407, USA \\ 4 Department of Finance, Fintech Center, and Big Data Research Center, Asia University, \\ Taichung 41354, Taiwan \\ 5 Department of Medical Research, China Medical University Hospital, Taichung City 404, Taiwan \\ 6 Department of Economics and Finance, The Hang Seng University of Hong Kong, Hong Kong \\ * Correspondence: wong@asia.edu.tw; Tel.: +886-4-2332-3456 (ext. 1946)
}

Received: 29 April 2020; Accepted: 28 May 2020; Published: 3 June 2020

\begin{abstract}
Corporate risk-taking behavior and investment is a crucial factor in order to seek higher profits and a better trading strategy. Competitive advantage and innovation, while maintaining profitability and state ownership, are considered as crucial resources. Furthermore, it is essential to connect the short-term and long-term business and investment objectives plus stakeholder's expectations to corporate sustainability and development. This connection is especially important in the context of transforming economies and getting better trading strategies. This study estimates the relationship between state ownership, profitability, corporate risk-taking behavior, and investment in Vietnam by using Generalized Method of Moments (GMM) methods. Using the data of 501 listed non-financial corporates during the period 2007-2015 from Ho Chi Minh City and Hanoi Stock Exchanges, we find that profitability is determined as a factor to reduce corporate risk-taking acceptance caused by the chances of entrenchment. Meanwhile, the impact of state ownership on the risk appetite of corporate has a non-linear effect. In particular, state ownership reduces corporate risk-taking behavior and investment but yet increases the risk-taking behavior and investment when the state ownership rate exceeds a threshold. One the one hand, this implies that the low level of state ownership not only prevents risk-taking behavior and investment but also results in more severe agency problems, causing unsustainability due to the imbalance of interests among various stakeholders. On the other hand, a dominant role of state ownership concentration causes a boost in corporate risk-taking decision-making in investment and trading strategy, leveraging the connection of significant external resources to deal with uncertain problems. The study contributes to existing theories of corporate governance in the context of a socialist-oriented market.
\end{abstract}

Keywords: market efficiency; state ownership; risk-taking behavior; investment; Vietnam; GMM; nonlinearity; trading strategy

JEL Classification: G30; G38 


\section{Introduction}

Risk-taking behavior and trading strategy play a vital role in the choice of corporate investment activities and are critical to creating the development of a corporate since they provide opportunities for innovation, and improve performance and competitive advantages (Cheng et al. 2020; Li and Liu 2017; Zhai et al. 2015; Shoham and Fiegenbaum 2002). Under uncertain business environments, corporates make different decisions that reflect strategic choices with uncertain consequences to improve their competitive advantage and performance (Hoskisson et al. 2016). For example, choices related to spending on research and development, acquisitions and divestitures, or competition actions. These choices mirror, as an indicator of, corporate risk-taking behavior. Stulz (2015) argued that corporates cannot maximize the shareholders' wealth and their revenue without taking risks. Thus, a corporate achieves efficiency, capital accumulation, and technological innovation through risk-taking activities and investments. However, excessive risk-taking behavior and investment can have a negative impact on corporate performance, since it consumes corporate resources such as capital, labor, and equipment. Excessive risk-taking can create an imbalance among all stakeholders, including the owner (Younas and Zafar 2019). Therefore, an investigation of corporate risk-taking behavior and investment is essential, not only for scholars but also for practicers in improving corporate governance.

Literature has shown that corporate risk-taking behavior, investment, and trading strategy is associated with structure and corporate governance (Faccio et al. 2016; Su et al. 2016), relying on the risk preferences and investment horizons of different shareholders (Vo 2018). Uddin (2016) believed that the government having ownership in a corporate directly influences its risk-taking decisions on investment and trading strategy, which determine the performance, survival, and growth of the corporate in the competitive market environment. Previous studies recognize that corporate activities are also affected by the unequal treatment between the public and non-public sectors in taking some risks to gain competitive advantages and achieve innovation (Zhou et al. 2016; Song et al. 2016). State-owned enterprises (SOEs), with their political connections, typically receive a multitude of financial and policy incentives that help to increase their performance and competitiveness (Ben-Nasr et al. 2015). Therefore, SOE managers believe that they can also reduce external uncertainties through political relations (Schweizer et al. 2019). However, political connections can derail corporate strategy in various ways (Fan et al. 2007). SOEs generally suffer from excessive interference and a lack of independence needed to conduct business activities (Bhatti and Sarwet 2011; Fan et al. 2007). They have also reoriented the goals and activities of corporates, thereby making them very different from governance principles (Abramov et al. 2017). Besides, SOE managers tend to focus on achieving social objectives and short-term political goals instead of maximizing their performance (Kang and Kim 2012). The above arguments raise an interesting question, that is whether or not corporates with state connections should take more risky investments to maintain their performance.

Moreover, Vietnam is identified as an excellent research sample for the influences of state ownership because it is not only an emerging transitional country but also has a history of a centrally-planned economy with the dominance of state and state-owned firms (Vo 2018). Although, since the 1986 reform, the rate of state property ownership among SOEs in Vietnam has declined significantly, the role of state ownership is still important because it is often considered as the "tactful" tool for the intervention and orientation of the government into the market (Ben-Nasr et al. 2015). Thus, our study provides helpful insights into the relationships among state ownership and corporate risk-taking behavior, investment, and trading strategy, thereby contributing to the management theories and practical implications in the context of Vietnam. There are three important goals for this study. Firstly, most of the existing literature focuses on SOEs' behavior in developed markets, whereas few are conducted for transitional economies (Khaw et al. 2016). Vietnam offers an ideal setting to examine the link between state ownership and risk-taking behavior, investment, and trading strategy for the typical characteristics of a socialist-oriented market and where SOEs have received strong support from the government. Moreover, prior studies on the Vietnamese market focus on investigating the relationship between state ownership and firm performance (e.g., Nguyen et al. 2019; Phung and Mishra 2015; 
Quang and Xin 2014; Nguyen et al. 2013) without pointing out whether state ownership promotes or reduces risk-taking behavior and investment by corporates. Therefore, the first goal of this study will fill this research gap.

Secondly, the study highlights the critical role of ownership structure and the duality of state-corporate relations. On the one hand, prior studies suggested a positive association between state ownership and corporate risk-taking behavior and investment (Zhai et al. 2015; Wang et al. 2008). On the other hand, other studies assert that state ownership is negatively associated with risk-taking activities and investments (Vo 2018; Zhou et al. 2016). Since government objectives reflect the interests of the government, discord might be caused between government and other shareholders in deciding corporate risk-taking activities and investments. Thus, the level of government shareholding can have a non-linear effect on corporate risk-taking behavior and investment (Uddin 2016). The next goal of this study will address this ambiguous issue. Thirdly, the study also considers the role of corporate efficiency and growth of revenue, debt, and fixed assets in association with corporate risk-taking acceptance. This study, therefore, adds to the current literature on the analysis of the risk-taking behavior and investment of SOEs in Vietnam, a transitional economy where state-owned corporates remain dominant, and thus enriching studies of state ownership. This contribution is essential in the context of a transition economy, often characterized by weak institutions and uncertainties.

In addition to the introduction, the structure of the paper is as follows: Section 2 presents the literature review. Section 3 states hypotheses and discuss the theory used in our paper, Section 4 describes empirical models and the data collection procedures in our paper, and Section 5 shows the results; Section 6 discusses, and Section 7 gives the conclusions and implications of the study.

\section{Literature Review}

Risk-taking behavior is a combination of several factors, such as agency theory, prospect theory, and resource dependence theory, as well as political connections (Sharma et al. 2020; Díez-Esteban et al. 2017; Uddin 2016). Risk-taking behavior illustrates the manager's risk-bearing with an organization's needs (Nobre et al. 2018). Risk-taking behavior reflects strategic choices with uncertain consequences to improve the competitive advantage and performance of the corporate. Thus, innovative strategies and competitive determinants will impact whether organizations will be risk-aversive or risk-assertive (Shoham and Fiegenbaum 2002).

Theoretically, the manager's risk-taking behavior reflects the effect of the level of equity holdings relative to managers' compensation, hence reflecting the agency problem. Typically, equity-based compensation will provide managers the incentive to undertake more risky but value-increasing investment projects and vice versa (Chen and Ma 2011). However, managers may be overconfident about their capabilities, lack understanding of market uncertainties, or try to find luck with risks (Kraus et al. 2011; Vereshchagina and Hopenhayn 2009). As such, it is accepted that risk does not yield a risk premium and does not lead to better performance. Therefore, Gillette et al. (2003) showed that the corporate insiders who are involved in the management of firms have both negative and positive incentives for taking risks due to the divergence of their interests in the firm. Thus, Hoskisson et al. (2016) proposed that the risk-taking behavior of a corporate can be significantly influenced by concentrated ownership and institutional ownership (the owner who holds their stock long term) because those owners have a stronger influence in corporate decision-making.

Friedman (1962) argued that the role of government is to establish a policy and legal framework, enforce rights to reduce monopolies, and prevent misconduct. However, the fact is that the government is also involved in the economy through different forms. For example, it can establish wholly-owned corporates in the early stages of market development and transfer ownership to private owners through full or partial privatization (Uddin 2016). This makes the government a majority or minority shareholder, which allows them to influence the decisions of the corporates, including risk-taking, directly. The empirical results of previous studies of state ownership and risk-taking behavior are also found to be disparate across countries, especially in transition economies (Song et al. 2016; 
Ben-Nasr et al. 2015). Khan et al. (2019) shed light on the prominent status of state-owners, that they are more likely to engage in social activities, indicating that they try to harmonize the interests of stakeholders. Thus, corporates with political connections have better performance and sustainability and less risk-taking behavior (Abramov et al. 2017).

The risk avoidance behavior of SOEs becomes stronger in markets with weak corporate governance and poor investor protection environments. Transition markets, such as Vietnam or China, are characterized by the dominance of state ownership in firms, especially in the past (Vo 2018; Luo et al. 2017). Moreover, in the defective business environment, corporates need to take more risks to reap higher profits. This makes the role of internal owners overwhelm the voices and interests of outside minority shareholders. The outside shareholders often succumb to the political pressure of the state, who is also a corporate owner (Durnev et al. 2004). However, SOEs do not need to take more risks because they already have a competitive advantage and better access to financial resources as well as a tax reduction (Vo 2018).

Moreover, instead of pursuing risky projects (uncertain return), state-owners appointed by the government are often asked to focus on socio-political objectives to ensure balance and the stability of society. State owners strive to protect previous achievements and the reputation of the government, such as creating jobs, social services, and public utilities, in political tenure, instead of investing in risky projects that might lead to uncertainty in markets (Boubakri et al. 2013; Fogel et al. 2008). In addition, SOE managers generally face difficulties in corporate governance because of state intervention, a lack of corporate governance skills, and a lack of the necessary independence (Lin et al. 2009). For this reason, they will not bet their political career on risky projects. This is especially true in socialist-oriented economies where the government often focuses on ensuring social stability and creating employment and, as such, avoid risky activities (Abramov et al. 2017; Fogel et al. 2008).

Conversely, some studies suggest that SOEs are willing to risk risky projects because they know that they receive strong support from the government to overcome the risks of the inefficient business environment (Farag and Mallin 2016; Zhai et al. 2015). Uddin (2016) claimed that internal owners involved in managing a business might be more risk-taking acceptant if the growth of corporate value is worth to them. Moreover, corporate state-owners also implement economic goals such as increasing government revenue through corporate income tax and dividends or developing capital markets through leading projects (De la Torre et al. 2007). These goals will be possible in a relatively stable, competitive, and transparent economy where SOE managers have enough independence and information to make their decisions (Uddin 2016; Vo 2018). Under increasing competitive pressure, SOEs also take risks to establish a leading position and contribute more to government revenues. The relationship with the government is itself a political pressure on SOEs, especially firms with the state being the majority shareholders. Therefore, Chong et al. (2018) suggested that state ownership can affect corporate risk-taking, but the non-linear effect of these political connections needs to be considered.

In summary, we realize that there are various findings regarding the influence of state ownership on firms' risk-taking behavior, not only related to aspects of agency problems but also political links and resource dependence. The tension in the nexus between profitability and stability gives rise to agency conflicts of interest. Therefore, this study explains this relationship by analyzing the influence of state ownership on the risk-taking behavior of listed corporates in Vietnam.

\section{Theories and Hypotheses}

Literature has considered that the risk-taking behavior of corporates could be explained through the lens of prospect theory and (Kahneman and Tversky 1979; Wong and Chan 2008). The prospective theory provides an explanation for an individual or organization's decision making under risk through the target. The individuals or organizations refuse to accept more risk when the expected result is higher than the target (i.e., profit). Conversely, they try to fill the gap by accepting more risk when the expected outcome is below the target (Frugier 2016). In other words, prospect theory explains risk-taking behavior through the identification of targeted outcomes, providing clues for trying to 
identify causal mechanisms that explain the different levels of risk-taking behavior at organizations. Agency theory also identifies that risk-taking avoidance is caused by conflicts between managers, who are concerned about market and business risks, and shareholders, who diversify their portfolios to earn higher profits (Jensen and Meckling 1976). Basically, the major key to driving a corporate's risk-taking behavior is expected profitability. When a corporate has already expected profitability and managers are compensated based on profitability, they prefer getting a stable income without taking any high-risk decisions. Therefore, the first hypothesis of the study is:

Hypothesis 1 (H1). Profitability has a negative impact on corporate risk-taking behavior.

Although agency theory refers to the conflict between managers and shareholders, it may also explain the behavior of state owners as inside owners. On the one hand, these authors maintain that outside shareholders prefer higher risk-taking for a higher return. Meanwhile, it is not the same case for inside owners such as managers or founding shareholders as their interests are tied to total wealth portfolios, personal gains and losses, and chances of entrenchment (Uddin 2016). State ownership also leads to the situation in which the de facto owner and SOE staff are state agents. Therefore, agency theory is also relevant to SOEs, e.g., the conflict of interest between shareholders and agents. SOE agents have little incentive to strive for achieving high economic efficiency; they tend to avoid risks to ensure safety for their positions and benefits. Su et al. (2016) argued that corporates with low risk-taking behavior often have more severe agency problems in order to uphold personal benefits.

Political connections are a useful link to external resources with considerable power and influence. Political connections are defined as informal social connections with officials at the constituent parts of public authorities (Sun et al. 2012). Uddin (2016) suggested that although a corporate's risk reflects the diversity of shareholder benefits, the government is the most politically powerful shareholder, regardless of its level of ownership. Thus, the government's interest reflects the level of risk-taking of corporates (Sharma et al. 2020). Previous research on political connections shows that it often has an impact on corporate operating, although there are some exceptions (Ang et al. 2013). The literature on political connection shows that the advantages of political relations can bring better results (Ling et al. 2016; Boubakri et al. 2013), competitive advantages (Frynas et al. 2006), higher bailout packages from the government (Faccio et al. 2006), or lower capital costs (Boubakri et al. 2012). SOE agents have little incentive to strive for achieving high economic efficiency. Instead, they tend to avoid risks to ensure safety for their positions and benefits. This leads to more severe incentive issues and a more pronounced loss of economic efficiency in SOEs (Young et al. 2014).

Thus, the existence of state ownership is considered to have a significant influence on the corporate's risk-taking behavior, thereby changing its investment and trading strategies to achieve high profitability. Based on the above arguments, it is important to state that the involvement of state ownership in a corporate leads to less risk-taking behavior, as in the below hypothesis:

Hypothesis 2 (H2). State ownership has a negative impact on corporate risk-taking behavior.

The theory of resource dependence emphasizes that corporates encounter dependencies when they need resources from outside, and influencing and responding to external dependencies is a key task of management (Lux et al. 2010). External links between firms and important sources are a coping mechanism to reduce the risk and uncertainty faced by corporates (Pfeffer and Salancik 1978). Government policy and regulation is a significant force in the external environment (Hillman et al. 1999). However, this interaction depends on the relative strength of the involved parties when internal and external organizations exchange resources and the dependence level of each (Casciaro and Piskorski 2005; Pfeffer and Salancik 1978). Therefore, a corporate will be more dependent on environmental uncertainty and the power of external resources (Santos and Eisenhardt 2005; Pfeffer and Salancik 1978). Díez-Esteban et al. (2017) discovered that this relationship is affected by the nature of the dominant shareholder, which is an important factor in corporate decision-making. This view was confirmed 
by Uddin (2016), who argued that (i) how the government, as the country's most powerful political institution, works with other insiders in public; and (ii) how the corporate and the government on the board affect decision making affect the corporate's attitude toward risk-taking, leading to more cautious reactions (accepting or avoiding risks), with changes in operating results.

SOEs receive external resources from political links in the forms of financial support from the government, tax breaks, or better access to information (Faccio 2010; Faccio et al. 2006). Besides, managers of large SOEs believe that they are "too big to fail" or, in other words, protected from bankruptcy due to the consequences of risky investments (Najid and Rahman 2011). Therefore, ownership links with the government transmit a signal to encourage venture investments because of the government advocates and protection of risky investments (Uddin 2016; Zhai et al. 2015). Although the government gives priority to socio-political goals to maximize social stability and employment (helping to ensure the government's political tenure), the government also receives a lot of taxes, dividends, and long-term capital gains if corporates can make successful risk investments. These goals are contradictory in the short term but not in the long run, so the economically stable government can provide more social and employment services to its citizens in a more sustainable way (Uddin 2016).

Thus, the study argues that corporate risk-taking behavior is affected because of the difference in the interests of state ownership and external shareholders, who are more concerned about performance, survival, and growth rather than focusing on both social and political objectives. It depends whether the government is a minority or majority shareholder, deciding whether SOEs managers become more prudent in reducing their risk taking to avoid earnings uncertainty. Conversely, if the government is a majority shareholder with a higher profits target, it puts a pressure on SOEs' managers to make riskier investments. Therefore, the state owners have a reasonable motivation to undertake risky decisions to achieve them. Besides, once successfully implementing risky investments, SOEs can help the government to ensure economic objectives in the long term, such as higher social stability and higher employment in the future. This awareness is important for monitoring ownership structure and restructuring trading strategies in SOEs for better investment and profitability. Thus, this study states the third hypothesis as follows:

Hypothesis 3 (H3). When the level of state ownership is below a threshold, as its ownership rises, the firm takes fewer risks. When the level of state ownership is above a threshold, the firm takes more risks.

\section{Data and Methodology}

In this section, we discuss the data and methodology being used in our study. We first discuss the data being used in our study.

\subsection{Data}

The data consist of 506 corporates listed on the Ho Chi Minh Stock Exchange (HOSE) and Hanoi Stock Exchange (HNX) from 2007 to 2015, with 4171 observations. This period is in an important stage of the equitization process with significant changes in government shares in state-owned corporates. In the period 2007-2011, the number of equitized corporates was 388, while 591 corporates were equitized, merged, and dissolved in the period 2011-2015. It was also marked by an important 929/QD-TTg decision, which was issued by the prime minister on approving the scheme on SOE restructuring in 2011-2015. Moreover, Vietnam was affected by the economic crisis, causing the stock market to be unfavorable and affecting its equitization process as well as the selection of investment and trading strategies in this period. Thus, this sample is useful and reliable for investigating the relationship between state ownership and risk-taking behavior to get better investments and trading strategies. Thus, we select the period in our study. This is a set of unbalanced panel data in which some corporates have more observations than others due to the availability of data, listing time, and our attempt to maximize the number of observations. The annual financial data and the ownership 
information of corporates are obtained from the FiinPro ${ }^{\circledR}$ Platform, affiliated with Nikkei Inc. and QUICK Corp.

\subsection{Variables}

Risk is a dependent variable that measures risk-taking behavior such that:

$$
\operatorname{Risk}_{R O A}=\frac{R O A_{i, t}}{\sigma R O A_{i}} \text { and Risk } k_{R O E}=\frac{R O E_{i, t}}{\sigma R O E_{i}}
$$

where $R O A_{i, t}$, and $R O E_{i, t}$ are the returns on assets and equity of corporate $i$ at time $t$, and $\sigma R O A_{i}$ and $\sigma R O E_{i}$ are the standard deviations of ROA and ROE for firm $i$ in the sample, respectively. We hypothesize that a more volatile performance is more relevant to the risk and risk-taking activities by corporates. Risk $k_{R O A}$ and Risk $R O E$ are indicators that are the inverse of corporate risk-taking behavior. Higher values for these indices means less risky behavior from corporates and vice versa. These measures are common proxies for corporate risk-taking in the extant literature and also have been used in many studies (Faccio et al. 2016; Vo 2018).

Profitability $_{i, t-1}$ are variables which measure the corporate's performance in earning profits from their assets or equity, represented by $R O A_{i, t-1}$ and $R O E_{i, t-1}$. Basically, the higher these indicators are, the more profitable the corporate is. The difference between $R O A$ and $R O E$ tends to reflect the debt burden. ROA shows the profit earned per unit of assets, and it, more importantly, reflects the ability of the corporate in using its resources to earn profits. Meanwhile, ROE reflects how effectively the corporate uses shareholder capital (Lin et al. 2019; Mun and Jang 2015).

$\mathrm{Gov}_{i, t}$ represents state ownership, which is measured by the percentage of state holdings of corporate $i$ at the end of year $t$. It can be understood that the state ownership level can be measured by shareholding by state agencies and SOEs. SOEs can be parent SOEs or non-parent SOEs (Hope 2013). Many listed corporates are originally spun off from their unlisted parent SOEs and floated on the stock market. Fro some listed corporates, their parent SOEs remain the major shareholder and control their resources in subsidiary firms.

Control variables $i, t$ is a set of variables that clearly explain corporate risk-taking behavior, including size $\left(\right.$ Size $\left._{i, t}\right)$, which is the logarithm of the total assets at the end of the year; fixed assets $\left(\right.$ Fixed $\left._{i, t}\right)$, which is the ratio of fixed assets to total assets; the level of mature debt $\left(D_{e b t} t_{i, t}\right)$, which is the short-term debt to total assets ratio; and growth $\left(\right.$ Growth $\left.h_{i, t}\right)$, which is the difference in revenue between $t$ and $t-1$ year of corporate $i$. These variables have been used in previous studies on corporate risk management (Thanh et al. 2019; Khuong et al. 2019; Nguyen et al. 2019; Mishra 2011).

\subsection{Models}

We extend the models of Faccio et al. (2016), Vo (2018), and others to develop the following new prior models to study the relationship between state ownership and corporate risk-taking behavior:

$$
\begin{gathered}
\text { Risk }_{i, t}=\alpha_{1}+\alpha_{2} \text { Profitabil ity }_{i, t-1}+\alpha_{3} \text { Gov }_{i, t}+\alpha_{4} \text { Size }_{i, t}+\alpha_{5} \text { Fixed }_{i, t}+\alpha_{6} \text { Debt }_{i, t}+\alpha_{7} \text { Growth }_{i, t}+\varepsilon_{i, t} \\
\text { Risk }_{i, t}=\beta_{1}+\beta_{2} \text { Profitability }_{i, t-1}+\beta_{3} \text { Gov }_{i, t}+\beta_{4} \text { Gov }_{i, t}^{2}+\beta_{5} \text { Size }_{i, t}+\beta_{6} \text { Fixed }_{i, t}+\beta_{7} \text { Debt }_{i, t}+\beta_{8} \text { Growth }_{i, t}+\varepsilon_{i, t}
\end{gathered}
$$

In the model in Equation (2), Govi,t represents state ownership, which is measured by the percentage of state holdings of corporate $i$ at the end of year $t$. We note that if $\beta_{3}$ is significantly positive and $\beta_{4}$ is significantly negative, then there is an inverted U-shaped relationship. On the other hand, if $\beta_{3}$ is significantly negative and $\beta_{4}$ is significantly positive, there is a U-shaped relationship between corporate risk-taking and state ownership. Taking the first derivative of both sides concerning Gov, we get: $G o v^{\prime}=\beta_{3}+2 \beta_{4}$ Gov. Finding the maximum value of Gov requires $G o v^{\prime}=0$. Solving this equation, we find the threshold value of Gov $(\varsigma)$ as follows:

$$
\varsigma=\frac{\beta_{3}}{-2 \beta_{4}}
$$


Based on the thresholds of Gov ( $\varsigma)$, this study separates the level of state ownership into two regimes: higher and lower than the threshold. Then, we check the robustness of the study's findings by re-developing two equations:

$$
\text { Risk }_{i t}=\left\{\begin{array}{l}
\beta_{11}+\beta_{12} \text { Profitability }_{i t-1}+\beta_{13} \text { Gov }_{i t}+\beta_{14} \text { Size }_{i t}+\beta_{15} \text { Fixed }_{i t}+\beta_{16} \text { Debt }_{i t} \\
+\beta_{17} \text { Growth }_{i t}+\left(\varsigma_{i}+\varepsilon_{i t}\right), \text { if Gov }<\varsigma \\
\beta_{21}+\beta_{22} \text { Profitability }_{i t-1}+\beta_{23} \text { Gov }_{i t}+\beta_{24} \text { Size }_{i t}+\beta_{25} \text { Fixed }_{i t}+\beta_{26} \text { Debt }_{i t} \\
+\beta_{27} \text { Growth }_{i t}+\left(\varsigma_{i}+\varepsilon_{i t}\right), \text { if Gov } \geq \varsigma .
\end{array}\right.
$$

By applying the GMM method, our findings will be confirmed as robustness if Gov $<(\varsigma)$ is negatively statistically significant for risk-taking behavior, and Gov $\geq(\varsigma)$ is positively statistically significant for risk-taking behavior and vice versa.

\subsection{Methodology}

It can be seen that both the models in Equations (1) and (2) are dynamic models with the participation of variable ROA in periods $t$ and $t-1$ as independent and dependent variables. Regression methods for panel data such as ordinary least squares (OLS), the fixed effects model (FEM), or the random-effects model (REM) may produce biased and inconsistent results because of the correlation between $\varepsilon_{i, t}$ and $R O A_{i, t-1}$, i.e., an endogenous problem. To solve this, we considered the difference Generalized Method of Moments (diff-GMM) method proposed by Arellano and Bond (1991), in which the models in Equations (1) and (2) are transformed into first-order difference models, and the lag of them is used as instrumental variables. This transformation eliminates the unobserved effects and allows the creation of orthogonal conditions between $\varepsilon_{i, t}$ and explanatory variables, thereby solving the endogenous problem. However, Arellano and Bover (1995) suggested that the variance of the estimates in diff-GMM may increase asymptotically and create considerable bias. Blundell et al. (2001) found that estimation in first differences had a large bias and low precision due to the inertial degree of consideration, even with a large number of individuals $(\mathrm{N})$.

Therefore, they proposed that the system Generalized Method of Moments method (sys-GMM), which displayed the lowest bias and highest precision for used series, is moderately or highly consistent. Moreover, the GMM method with two steps has a higher efficiency than that with one step due to the application of a suboptimal weighting matrix, which then produced the bias of uncorrected standard errors when the instrument count was high. Therefore, Roodman (2009) suggested a principle that the number of instrumental variables must be less or equal to the number of groups (N) as a reasonable condition. Both estimation methods are considered appropriate only when two conditions are met: (1) The suitability of the instrument variables is determined through the Hansen or Sargan tests. Specifically, the higher the $p$-value of the Sargan and Hansen statistics is, the more likely that the null hypothesis is accepted. (2) There is no second-order autocorrelation phenomenon in the error terms through the AR (2) test.

\section{Results and Findings}

\subsection{Descriptive Statistics}

Table 1 presents the descriptive statistics of the variables in this study.

Table 1 shows the summary statistics of all the variables. It presents the descriptive statistics of the entire sample of 4171 corporate-year observations. The mean (median) risk-taking behavior $\left(\operatorname{Risk}_{R O A}\right)$ of the sample corporates is 2.169 (1.832), lower than that for Risk $R O E$ at 2.307 (1.888). The mean (median) state ownership (Gov) is only $2.73 \%(2.80 \%)$, notably lower than the Vo (2018) observations. The difference is mainly caused by the sample size; Vo (2018) used an average of 2000 observations in the Ho Chi Minh Stock Exchange (HoSE), while our study uses data of listed corporates in the Ho Chi Minh Stock Exchange (HoSE) and Hanoi Stock Exchange (HNX), with 4171 observations. 
Table 1. Definition and description of variables.

\begin{tabular}{|c|c|c|c|c|c|c|}
\hline Code & Definition & Obs & Mean & Median & Min & Max \\
\hline Risk $_{\text {Roa }}$ & Risk-taking behavior based on $R o a$ & 4171 & 2.169 & 1.832 & -2.772 & 12.794 \\
\hline Risk $_{\text {Roe }}$ & Risk-taking behavior based on Roe & 4171 & 2.307 & 1.888 & -2.917 & 18.066 \\
\hline Roa & Return/total assets & 4171 & 0.069 & 0.054 & -0.646 & 0.784 \\
\hline Roe & Return/equity & 4171 & 0.132 & 0.133 & -7.836 & 0.982 \\
\hline Gov & Percentage of state holdings by the state & 4171 & 0.273 & 0.280 & 0.000 & 0.967 \\
\hline Size & Logarithm of total assets & 4171 & 26.676 & 26.584 & 21.370 & 31.906 \\
\hline Fixed & Fixed assets/total assets & 4171 & 0.282 & 0.230 & 0.000 & 0.978 \\
\hline Debt & Short-term debt/total debt & 4171 & 0.624 & 0.785 & 0.000 & 1.000 \\
\hline Growth & Revenue $_{t} /$ Revenue $_{t-1}$ & 4171 & 0.136 & 0.118 & -4.643 & 7.070 \\
\hline
\end{tabular}

(Source: HOSE and HNX).

\subsection{Correlation Matrix}

Table 2 presents the correlation matrix of the variables. It can be seen that the coefficients between state ownership and the two variables of risk-taking are significantly positive, indicating that higher state ownership is associated with a lower level of corporate risk-taking behavior. Moreover, the table also shows a negative correlation between the variables of risk-taking and the firm size, fixed assets, and level of debt, and a positive correlation with growth.

Table 2. Definition and description of variables.

\begin{tabular}{|c|c|c|c|c|c|c|c|c|c|}
\hline & Risk $_{\text {Roa }}$ & Risk $_{\text {Roe }}$ & Roa & Roe & Gov & Size & Fixed & Debt & Growth \\
\hline Risk $_{\text {Roe }}$ & $0.86^{* * *}$ & 1.00 & & & & & & & \\
\hline Roe & $0.44^{* * *}$ & $0.42^{* * *}$ & $0.68^{* * *}$ & 1.00 & & & & & \\
\hline Gov & $0.17^{* * *}$ & $0.18^{* * *}$ & $0.11^{* * *}$ & $0.11^{* * *}$ & 1.00 & & & & \\
\hline Size & $-0.07 * * *$ & $-0.08^{* * *}$ & $-0.07 * * *$ & 0.02 & $0.06^{* * *}$ & 1.00 & & & \\
\hline Debt & $-0.13^{* * *}$ & $-0.11^{* * *}$ & $-0.19 * * *$ & $-0.08^{* * *}$ & $-0.16^{* * *}$ & $0.04^{* *}$ & $-0.28 * * *$ & 1.00 & \\
\hline Growth & $0.14^{* * *}$ & $0.13^{* * *}$ & $0.18^{* * *}$ & $0.20 * * *$ & $-0.05^{* * *}$ & 0.03 * & 0.01 & -0.04 * & 1.00 \\
\hline
\end{tabular}

Note: $\left({ }^{*}\right),(* *)$, and $(* * *)$ are $10 \%, 5 \%$, and $1 \%$, respectively.

\subsection{Relationship between State Ownership and Corporate Risk-Taking Behavior}

Empirical results of the models in Equations (1) and (2) are presented in Tables 3 and 4, respectively. It can be seen that the conditions of the GMM methods are satisfied. The p-value from the Hansen and Sargan tests is large, implying that the GMM regression results are reliable and that the chosen instrumental variables in the models are appropriate. The p-value of the AR (2) test for the first-order difference of error terms also shows that there is no correlation between the error terms and the explanatory variables at all levels.

The empirical results provide some interesting contributions. Firstly, the Gov and Risk exhibit a positive correlation and are statistically significant at 1\%,5\%, and 10\% with the GMM methods. As a higher value of RISK implies lower risk-taking behavior, this indicates that high state ownership (proxied by Gov) is associated with less risk-taking activity. This finding is consistent with previous studies, which also suggest that increased state ownership reduces corporate risk appetite (Vo 2018; Khaw et al. 2016; Boubakri et al. 2013). Uddin (2016) mentioned that the government also has political and social interests, such as in controlling the employment rate, ensuring social stability, and pursuing political and economic benefits related to increasing government income from dividends and corporate taxes. Thus, if economic objectives and even political targets are the priority in the long-term, the government may actively support SOEs; hence, there will be an increase in risky behavior by SOEs. However, agency problems may arise in this situation as the government has to deal with other shareholders to develop a governance mechanism that is deemed appropriate to 
the interests of different groups of shareholders (Sur et al. 2013). This is an uneasy situation; hence, whether or not the state ownership increases risky behavior is unclear, as major shareholders' interests ultimately determine corporate risk-taking behavior. Based on these arguments, this study examines the non-linear relationship between state ownership and risk-taking, presented in Table 4 as follows.

Table 3. State ownership and corporate risk-taking behavior.

\begin{tabular}{|c|c|c|c|c|}
\hline \multirow{2}{*}{ Variable } & \multicolumn{2}{|c|}{ RISK $_{R O A}$} & \multicolumn{2}{|c|}{ RISK $_{R O E}$} \\
\hline & 2-Steps Diff-GMM & 2-Steps Sys-GMM & 2-Steps Diff-GMM & 2-Steps Sys-GMM \\
\hline Lag of & $4.819^{* *}$ & $11.339^{* * *}$ & $1.633^{*}$ & $4.883^{* * *}$ \\
\hline profitability & [2.08] & [4.50] & [1.70] & [4.44] \\
\hline \multirow[t]{2}{*}{ Gov } & $3.283 *$ & $7.485^{* * *}$ & $4.058^{* *}$ & $9.348^{* * *}$ \\
\hline & [1.73] & [4.62] & [2.07] & [4.57] \\
\hline \multirow[t]{2}{*}{ Size } & $-1.016 * *$ & 0.261 & $-1.385^{* * *}$ & 0.013 \\
\hline & {$[-2.28]$} & [0.70] & {$[-3.30]$} & [0.03] \\
\hline \multirow[t]{2}{*}{ Fixed } & $-4.987 * * *$ & $-3.696 * *$ & $-5.479 * * *$ & $-4.560 * * *$ \\
\hline & {$[-3.85]$} & {$[-2.55]$} & {$[-4.16]$} & {$[-2.82]$} \\
\hline \multirow[t]{2}{*}{ Debt } & $-1.576^{* * *}$ & $-2.292 * * *$ & $-1.754^{* * *}$ & $-2.368^{* * *}$ \\
\hline & [-3.05] & {$[-3.50]$} & {$[-3.04]$} & {$[-2.75]$} \\
\hline \multirow[t]{2}{*}{ Growth } & $1.609 * * *$ & $1.514^{* * *}$ & $1.637 * * *$ & $1.657 * * *$ \\
\hline & [6.17] & [4.54] & [6.29] & [4.34] \\
\hline $\begin{array}{l}\text { AR (1) test } \\
\text { ( } p \text {-value) }\end{array}$ & 0.000 & 0.000 & 0.000 & 0.000 \\
\hline $\begin{array}{l}\text { AR (2) test } \\
\text { ( } p \text {-value) }\end{array}$ & 0.858 & 0.812 & 0.754 & 0.282 \\
\hline $\begin{array}{l}\text { Sargan test } \\
\text { ( } p \text {-value) }\end{array}$ & 0.898 & 0.543 & 0.908 & 0.368 \\
\hline $\begin{array}{l}\text { Hansen test } \\
\text { ( } p \text {-value) }\end{array}$ & 0.838 & 0.871 & 0.974 & 0.642 \\
\hline Num. IV & 40 & 43 & 40 & 43 \\
\hline Groups & 501 & 501 & 501 & 501 \\
\hline
\end{tabular}

Note: $\left({ }^{*}\right),(* *)$, and $\left({ }^{* *}\right)$ are $10 \%, 5 \%$, and $1 \%$, respectively. z-statistic in [ ].

The results from the GMM methods show a clearer non-linear relationship between state ownership and corporate risk-taking. In particular, the coefficient of Gov, $\beta_{3}$ is positive, whereas the coefficients of $\mathrm{Gov}^{2}, \beta_{4}$ are negative and significant at the 5\% and $10 \%$ levels, respectively. The thresholds $(\varsigma)$ for state ownership obtained from Equation (3) range from $40 \%$ to $48 \%$. This result implies that for SOEs with minor government holdings, the principal-principal conflicts between minority shareholders and controlling shareholders is more serious due to the pressure from minority shareholders, who have political and economic interests, and majority shareholders, who require a higher yield and profitability. Therefore, SOE managers tend to be more prudent in risk-taking to avoid earnings uncertainty (Uddin 2016; Boubakri et al. 2013). On the contrary, if the government plays the role of the majority shareholder, it may encourage SOEs to take on risky projects for the economy, which may only be done by SOEs due to their importance and financial capability. Additionally, these SOEs generally receive greater government support in accessing finance and resources to cope with uncertain risks from the market (Zhai et al. 2015; Farag and Mallin 2016). 
Table 4. Non-linear relationship between state ownership and corporate risk-taking behavior.

\begin{tabular}{|c|c|c|c|c|}
\hline \multirow{2}{*}{ Variable } & \multicolumn{2}{|c|}{ RISK $_{R O A}$} & \multicolumn{2}{|c|}{ RISK $_{R O E}$} \\
\hline & 2-Steps Diff-GMM & 2-Steps Sys-GMM & 2-Steps Diff-GMM & 2-Steps Sys-GMM \\
\hline Lag of & $4.757^{* *}$ & $9.148^{* * *}$ & $2.171 * *$ & $3.461 * * *$ \\
\hline profitability & [1.87] & [3.44] & [2.32] & [2.86] \\
\hline \multirow[t]{2}{*}{ Gov } & $11.253^{* *}$ & $19.934^{* * *}$ & $12.018^{* *}$ & $24.520 * * *$ \\
\hline & [2.03] & [2.94] & [2.34] & [3.61] \\
\hline \multirow[t]{2}{*}{ Gov $^{2}$} & $-14.064^{* *}$ & $-20.476^{* *}$ & $-13.842 * *$ & $-26.680^{* * * *}$ \\
\hline & {$[-1.96]$} & {$[-2.15]$} & {$[-2.03]$} & {$[-2.71]$} \\
\hline \multirow[t]{2}{*}{ Size } & -0.753 & 0.228 & -0.567 & 0.123 \\
\hline & [-1.59] & [0.55] & {$[-1.61]$} & [0.29] \\
\hline \multirow[t]{2}{*}{ Fixed } & $-4.848^{* * *}$ & $-4.529 * * *$ & $-3.748^{* * *}$ & $-3.893^{* * *}$ \\
\hline & {$[-3.55]$} & {$[-2.91]$} & {$[-3.32]$} & {$[-2.65]$} \\
\hline \multirow[t]{2}{*}{ Debt } & $-2.052 * * *$ & $-2.679 * * *$ & $-2.315^{* * *}$ & $-2.979 * * *$ \\
\hline & {$[-3.58]$} & {$[-3.75]$} & {$[-3.83]$} & {$[-3.44]$} \\
\hline \multirow[t]{2}{*}{ Growth } & $1.418^{* * *}$ & $1.382^{* * *}$ & $1.325^{* * *}$ & $1.210^{* * *}$ \\
\hline & [5.87] & [4.39] & [5.32] & [3.45] \\
\hline $\begin{array}{l}\text { AR (1) test } \\
\text { ( } p \text {-value) }\end{array}$ & 0.000 & 0.000 & 0.000 & 0.000 \\
\hline $\begin{array}{l}\text { AR (2) test } \\
(p \text {-value) }\end{array}$ & 0.625 & 0.585 & 0.793 & 0.799 \\
\hline $\begin{array}{l}\text { Sargan test } \\
(p \text {-value) }\end{array}$ & 0.874 & 0.938 & 0.845 & 0.872 \\
\hline $\begin{array}{l}\text { Hansen test } \\
\text { ( } p \text {-value) }\end{array}$ & 0.799 & 0.902 & 0.965 & 0.946 \\
\hline Num. IV & 40 & 62 & 40 & 62 \\
\hline Groups & 501 & 501 & 501 & 501 \\
\hline Gov $(\varsigma)$ & 0.400 & 0.487 & 0.434 & 0.456 \\
\hline
\end{tabular}

Note: $(*),(* *)$, and $(* * *)$ are $10 \%, 5 \%$, and $1 \%$, respectively. $z$-statistic in [ ].

Tables 3 and 4 also provide results that can shed light on the risk-taking behavior of Vietnamese corporates. Firstly, profitability is found to have a significant reversal of impact on risky behavior in all equations. They illustrate that managers refuse to accept more risky behavior if the target profitability increases. Another explanation is that managers are rewarded based on the profits of the company's operations; they prefer a stable income with low-risk decisions. This study also provides reliable estimates of the impact of short-term debt rates and the degree of the use of fixed assets that promotes the corporate's risk appetite, with $1 \%$ statistical significance. Businesses may be more risk-taking in the search for more profitable projects for debt repayments, primarily short-term debts. Similarly, an increase in fixed assets requires businesses to look for more projects to improve the earnings of their assets, leading to higher risk appetite. Secondly, the level of corporate performance in the previous period is negatively related to the level of risk tolerance in this period. Greater efficiency is associated with higher cash flow, hence less risk-taking in this period. Finally, it is expected that firm size has a relationship with risk acceptance, but the empirical results are not precise and consistent. These findings are relevant for shareholders in monitoring their corporates to avoid agency problems and improve corporate performance.

\subsection{Robustness Test}

In this section, this study examines the robustness of empirical results, according to Equation (4). Based on the thresholds of Gov ( $\varsigma$ ) presented in Table 4, this study separates the level of state ownership into two regimes: higher and lower than the threshold. According to the literature review, this study assumes that a high level of state ownership increases corporate risk-taking behavior. In other words, Gov (ऽ) has a negative relationship with the Z-score and vice versa. Using GMM methods, we found consistent results, which are presented in Table 5. 
Table 5. Relationship between state ownership and corporate risk-taking behavior

\begin{tabular}{|c|c|c|c|c|c|c|c|c|}
\hline \multirow[b]{2}{*}{ Variable } & \multicolumn{2}{|c|}{ RISK $_{R O A}$} & \multicolumn{2}{|c|}{$\mathrm{RISK}_{\mathrm{ROA}}$} & \multicolumn{2}{|c|}{ RISK $_{R O E}$} & \multicolumn{2}{|c|}{ RISK $_{R O E}$} \\
\hline & $\begin{array}{r}\text { 2-Steps } \\
\text { Diff-GMM }\end{array}$ & $\begin{array}{r}\text { 2-Steps } \\
\text { Diff-GMM }\end{array}$ & $\begin{array}{r}\text { 2-Steps } \\
\text { Sys-GMM }\end{array}$ & $\begin{array}{r}\text { 2-Steps } \\
\text { Sys-GMM }\end{array}$ & $\begin{array}{r}\text { 2-Steps } \\
\text { Diff-GMM }\end{array}$ & $\begin{array}{r}\text { 2-Steps } \\
\text { Diff-GMM }\end{array}$ & $\begin{array}{r}\text { 2-Steps } \\
\text { Sys-GMM }\end{array}$ & $\begin{array}{r}\text { 2-Steps } \\
\text { Sys-GMM }\end{array}$ \\
\hline $\begin{array}{l}\text { Lag of } \\
\text { profitability }\end{array}$ & $5.314^{* *}$ & $5.619^{* *}$ & $10.032^{* * *}$ & $10.412^{* * *}$ & $2.039 * *$ & $2.026^{* *}$ & $3.876^{* * *}$ & $3.512 * * *$ \\
\hline & [2.15] & [2.23] & [3.58] & [3.25] & [2.11] & [2.10] & [2.80] & [2.65] \\
\hline Gov & $\begin{array}{r}7.434^{* *} \\
{[2.01]}\end{array}$ & $\begin{array}{r}2.753 * \\
{[1.71]}\end{array}$ & $\begin{array}{r}13.661 * * * \\
{[3.00]}\end{array}$ & $\begin{array}{r}8.570 * * * \\
{[4.40]}\end{array}$ & $\begin{array}{r}9.792^{* * *} \\
{[2.65]}\end{array}$ & $\begin{array}{r}3.667 * * \\
{[2.30]}\end{array}$ & $\begin{array}{r}16.515^{* * * *} \\
{[3.11]}\end{array}$ & $\begin{array}{r}8.188^{* * *} \\
{[4.65]}\end{array}$ \\
\hline Gov $\geq(\varsigma)$ & $\begin{array}{r}-4.861 \text { * } \\
{[-1.87]}\end{array}$ & & $\begin{array}{r}-6.367 * \\
{[-1.75]}\end{array}$ & & $\begin{array}{r}-6.089 * * \\
{[-2.21]}\end{array}$ & & $\begin{array}{r}-8.282^{* *} \\
{[-1.93]}\end{array}$ & \\
\hline Gov $<(\varsigma)$ & & $\begin{array}{r}4.153 * \\
{[1.66]}\end{array}$ & & $\begin{array}{r}9.138^{* *} \\
{[2.13]}\end{array}$ & & $\begin{array}{r}6.043^{* *} \\
{[2.19]}\end{array}$ & & $\begin{array}{r}9.391 * * \\
{[2.29]}\end{array}$ \\
\hline Size & $\begin{array}{r}-0.686 \\
{[-1.47]}\end{array}$ & $\begin{array}{l}-0.515 \\
{[-1.31]}\end{array}$ & $\begin{array}{r}0.412 \\
{[1.02]}\end{array}$ & $\begin{array}{r}0.606 \\
{[1.29]}\end{array}$ & $\begin{array}{r}-0.565 \\
{[-1.57]}\end{array}$ & $\begin{array}{l}-0.569 \\
{[-1.63]}\end{array}$ & $\begin{array}{r}0.155 \\
{[0.37]}\end{array}$ & $\begin{array}{r}0.188 \\
{[0.46]}\end{array}$ \\
\hline Fixed & $\begin{array}{r}-4.371^{* * *} \\
{[-3.42]}\end{array}$ & $\begin{array}{r}-3.884^{* * * *} \\
{[-3.32]}\end{array}$ & $\begin{array}{r}-3.745^{* *} \\
{[-2.50]}\end{array}$ & $\begin{array}{r}-3.789 * * \\
{[-2.37]}\end{array}$ & $\begin{array}{r}-3.329 * * * \\
{[-3.13]}\end{array}$ & $\begin{array}{r}-3.297^{* * * *} \\
{[-3.08]}\end{array}$ & $\begin{array}{r}-3.408^{* * * *} \\
{[-2.23]}\end{array}$ & $\begin{array}{r}-2.940 * * * \\
{[-2.11]}\end{array}$ \\
\hline Debt & $\begin{array}{r}-1.813^{* * * *} \\
{[-3.30]}\end{array}$ & $\begin{array}{r}-1.779 * * * \\
{[-3.30]}\end{array}$ & $\begin{array}{r}-2.559 * * * \\
{[-3.48]}\end{array}$ & $\begin{array}{r}-2.996^{* * * *} \\
{[-2.96]}\end{array}$ & $\begin{array}{r}-2.165^{* * * *} \\
{[-3.60]}\end{array}$ & $\begin{array}{r}-2.189 * * * \\
{[-3.60]}\end{array}$ & $\begin{array}{r}-2.698^{* * * *} \\
{[-3.12]}\end{array}$ & $\begin{array}{r}-2.826^{* * *} \\
{[-3.22]}\end{array}$ \\
\hline Growth & $\begin{array}{r}1.385^{* * * *} \\
{[5.89]}\end{array}$ & $\begin{array}{r}1.417^{* * *} \\
{[6.14]}\end{array}$ & $\begin{array}{r}1.291^{* * * *} \\
{[4.18]}\end{array}$ & $\begin{array}{r}1.152 * * * \\
{[2.87]}\end{array}$ & $\begin{array}{r}1.316^{* * *} \\
{[5.37]}\end{array}$ & $\begin{array}{r}1.321^{* * *} \\
{[5.35]}\end{array}$ & $\begin{array}{r}1.193^{* * *} \\
{[3.41]}\end{array}$ & $\begin{array}{r}1.187^{* * *} \\
{[3.49]}\end{array}$ \\
\hline $\begin{array}{l}\mathrm{AR}(1) \text { test } \\
(p \text {-value })\end{array}$ & 0.000 & 0.000 & 0.000 & 0.000 & 0.000 & 0.000 & 0.000 & 0.000 \\
\hline $\begin{array}{l}\text { AR (2) test } \\
\text { ( } p \text {-value) }\end{array}$ & 0.712 & 0.739 & 0.587 & 0.375 & 0.939 & 0.945 & 0.686 & 0.896 \\
\hline $\begin{array}{l}\text { Sargan test } \\
(p \text {-value) }\end{array}$ & 0.848 & 0.927 & 0.926 & 0.897 & 0.846 & 0.886 & 0.807 & 0.873 \\
\hline $\begin{array}{l}\text { Hansen } \\
\text { test } \\
(p \text {-value) }\end{array}$ & 0.780 & 0.933 & 0.893 & 0.856 & 0.981 & 0.989 & 0.862 & 0.962 \\
\hline Num. IV & 41 & 52 & 42 & 26 & 60 & 61 & 54 & 62 \\
\hline Groups & 501 & 501 & 501 & 501 & 501 & 501 & 501 & 501 \\
\hline Gov $(\varsigma)$ & 0.400 & 0.400 & 0.487 & 0.487 & 0.434 & 0.434 & 0.456 & 0.456 \\
\hline
\end{tabular}

Note: $\left({ }^{*}\right),(* *)$, and $\left(^{* * *}\right)$ are $10 \%, 5 \%$, and $1 \%$, respectively and $z$-statistic in [ ]. 
The results from robust tests show that state ownership tends to reduce corporate risk-taking appetite. However, when state ownership exceeds the threshold ( $\varsigma$ is approximately $40 \%$ ), it tends to increase risk-taking behavior (significant at 5\% and 10\%) and vice versa. These results are consistent for both Risk $_{R O A}$ and Risk $_{R O E}$, confirming that state ownership has a significant impact on the level of corporate risk tolerance. In addition, for other factors such as Fixed, Debt, and Growth is consistently found statistical significance in empirical models.

\section{Discussion}

As discussed in the literature review, a decrease in risk-taking acceptance yields a serious agency problem that interferes with political connections. The serious agency problem forces internal managers to take less risky behavior to seize opportunities for entrenchment and benefits, which is met by outside shareholder costs (Uddin 2016). State connection forces SOEs to ensure stability for social goals rather than seeking risky projects to get higher profitability (Boubakri et al. 2013). Additionally, SOEs with state ownership have advantages in accessing information, financial resources, and state support through their political connections (Vo 2018). Indeed, our results show that SOEs have little incentive to engage in any risk-taking activity to gain a competitive position. Another reason is that SOE managers, who are generally appointed by the state, often face difficulties in corporate governance because of excessive control from the state and a lack of business management skills (Lin et al. 2009). They, therefore, hesitate to engage in any risky activity.

On the other hand, according to the theory of resource dependence, links to external sources are a coping mechanism to reduce risk and uncertainty (Pfeffer and Salancik 1978). Government policy and regulation are major forces in the external resources (Hillman et al. 1999), and they change the decision-making on any risk-taking behavior for corporates. In our case, the high state ownership in the SOEs reflects the role of SOEs in the market and economy as strategic corporates. Thus, these entities have available resources from the government to promote risky activities to achieve profitable investments and get better trading strategies under uncertainties (Zhai et al. 2015; Farag and Mallin 2016), a condition that can discourage other common enterprises.

Our empirical findings contribute to the literature on the ownership structure's operating and monitoring to avoid agency issues and get better investment and trading strategies. The agency problem has existed and is continuously controversial in transition economies where the state has significant shares in enterprises, and investor protection is often weaker than in developed countries (Vo 2018). Chen et al. (2013) use transaction costs and agency theory to propose that ownership structure provides an important mechanism to realize the necessary resources for innovation and competition in the context of emerging markets, thereby affecting the risk appetite of the corporates. Although risk-taking behavior is important for achieving a better trade and investment strategy (Faccio et al. 2011), state ownership relationships reduce the firm's craving for risk through conservatives, social goals, and government support. On the other hand, Su et al. (2016) suggest that a strong incentive for corporates to minimize their risk-taking activities is to protect the dominant shareholders' benefits. Similarly, Nguyen et al. (2019) show that lower than $25 \%$ or higher than $75 \%$ state ownership will yield positive effects on corporate performance in Vietnam, while it is negatively impacted by the level of state ownership between $25 \%$ and $75 \%$. Our results, once again, support the importance of ownership restructuring as an important mechanism to enhance accountability and create incentives for corporate governance.

\section{Conclusions}

The sustainability of corporates differs because their ability to respond to uncertain economic conditions is different. Due to the uncertainty of the economic situation, corporates taking high risks may have higher agency costs, resulting in a negative impact on their sustainable development, investment, and trading strategy. The deviation in corporate profitability is a crucial representation of risk-taking behavior in order to seek profit, carry on their investment, and alter their trading strategy, while state ownership is considered as a competitive advantage, connecting the long-term business 
objectives and stakeholder expectations that relate to corporate sustainability, investment, and trading strategy, especially in the context of transforming economies. On the one hand, through the political connection, state ownership ensures corporate objectives which serve as the foundation for ensuring sustainable and steady development. On the other hand, it also creates an agency problem that can lead to an imbalance of interests of stakeholders, seriously affecting the sustainability, investment, and trading strategy of the firms. The influence of a state relationship can promote risky behaviors of firms, thereby shifting the costs of the stakeholder's sustainability into risky investments for the benefits of majority shareholders. Thus, the relationship between risk-taking behavior and state ownership is an exciting topic, especially in transition economies such as Vietnam. On the other hand, Vietnam is undergoing a robust privatization process with a shift in ownership structure from the state to the private sector, which is expected to boost economic growth as well as market development. The state still owns strategic and important corporates to maintain its dominant role in the socialist-oriented market. Therefore, insights into the role of state ownership help to promote radical reforms and policies to facilitate the development of corporates and the economy.

This study sheds light on the relationship between state ownership and the risk-taking behavior of corporates in Vietnam. Employing the GMM method on data of 501 listed corporates from 2007 to 2015, this study found substantial evidence for the negative impacts of state ownership on the risk-taking behavior of corporates. Firstly, the study provides evidence that state ownership reduces corporate risk-taking behavior. This result shows that state-owned corporates are controlled to ensure stability instead of taking risks for higher profits. This may be because SOEs already have competitive advantages and resources available; therefore, managers have no incentive to take the risk and choose a trading strategy having less risk. Moreover, according to the theory of the agency problem, SOE managers are often appointed by the state, and they are more interested in social-political objectives than activities that promote profits, get better investment opportunities, and obtain a better trading strategy for the corporate. It, therefore, improves the corporate image to the public and provides a competitive advantage in uncertain economic conditions. Secondly, the results show that political connections are a double-edged sword, as SOEs with stronger political connections may be more risk-taking and make investments and take trading strategies having higher risk but getting higher profit. The study also shows that state ownership has a U-shaped nonlinear relationship with the corporate's risk-taking and investment behavior. When the state is the majority shareholder, the SOE managers are under higher pressure for achieving economic objectives. This causes serious agency problems because higher economic pressure translates the interests of stakeholders into more risky investments and trading strategies for the majority shareholder's goals. The study highlights the need to develop an effective monitoring mechanism as well as corporate governance for SOEs. This is clear and relevant in the context of the transition economy when the state is promoting the equitization process. It leads to policy recommendations on the level of state ownership, which should include involvement in strategic or non-strategic corporates. Finally, the study also finds that an increase in corporate efficiency and growth of revenue would reduce corporate risk-taking behavior and investment activity, while an increase in debt and fixed assets would put pressure on corporates to implement more risk-taking behavior and investment. The results contribute to existing theories of corporate governance in the context of the socialist-oriented markets.

This is in line with the context of Vietnam with the presence of the weak and uncertain environment and the significant role of the government in accessing financial and business resources (Luo et al. 2017). In addition, state ownership may lead to a dependence of corporates on state support instead of actively innovating and making excellent investments to increase competitiveness. It might be suitable for SOEs in the early stages of development, but it may cause inequality in competition, leading to the crowding out of the private enterprises in the long-term (Van Thang and Freeman 2009). However, the extensive results show that the role of state ownership depends on the level of ownership; it can have a U-shape relationship with corporate risk-taking investment. Accordingly, if state ownership is the majority, the government can require SOEs to undertake important and risky projects for economic 
goals. Vo (2018) noted that risk-taking is of importance for the development of a corporate since it allows businesses to gain competitive advantage and innovation.

Therefore, this study provides some practical implications. First, the government should clearly define strategic and non-strategic businesses and restrict their investment and trading strategies. State ownership in non-strategic businesses not only limits incentives for finding corporate profits, investment, and trading strategies but also causes serious agency problems. As a result, privatization is an important strategy to promote the development of corporates in transition economies, especially small and medium private firms. Second, this study also supports the role of the government in holding strategic businesses. With support from the government, SOE managers can promote corporate activities to gain a dominant position in the socialist-oriented economy without hesitation about risky situations and investment. This not only offers a competitive advantage to strategic businesses but also facilitates innovation among businesses, thereby boosting sustainable development and getting better investment and trading strategies.

This study also has some limitations. Although the main relationship between state ownership and risk-taking has been demonstrated, there are still potential factors that influence this relationship, such as monitoring roles, the business environment, and economic crisis. Therefore, future studies should expand the analytical framework for a comprehensive view. Furthermore, although the validity and reliability of the data have been determined, the number and time of data should be improved in subsequent studies to ensure robustness and avoid possible bias. Finally, this paper studies the profitability and risk-taking behavior in investment and trading strategies for state-owned enterprises. An extension of our paper could study other behaviors, other investments, and other trading strategies. This could include an extension of Tobin (1958), Pratt (1964), Kogan and Wallach (1964), Slovic (1964), Wong and Li (1999), Li and Wong (1999), Wong (2006, 2007), Wong and Ma (2007), Qiao et al. (2013), Guo and Wong (2019), and many others to study other types of risk-loving behavior; of Wong and Chan (2008), Lean et al. (2010), Qiao et al. (2012), Clark et al. (2015), and others to study a mixture of both risk-averse and risk-loving behavior; of Egozcue et al. (2015), Guo et al. (2017b), and Guo and Wong (2019) to study regret-aversion behavior; of Guo et al. (2020) to include the behavior of disappointment; of Munkh-Ulzii et al. (2018) to study herding behavior; and of Guo et al. (2017a), Chan et al. (2019), and Wong and Qiao (2020) to use other types of utility functions to study the behavior of risk loving. Scholars could also extend Lean et al. (2007), Chiang et al. (2008), Qiao and Wong (2015), Tsang et al. (2016), Guo et al. (2017b), and others to examine the existence of any arbitrage opportunity; extend Abid et al. (2014), Wong et al. (2008, 2018), Li et al. (2018), and others to study other investment behaviors; and extend Wong et al. (2001, 2003), Lam et al. (2007), Lam et al. (2010, 2012), Kung and Wong (2009a, 2009b), Egozcue and Wong (2010), Egozcue et al. (2011), Lean et al. (2012), Chan et al. (2012, 2014), Fabozzi et al. (2013), Hoang et al. (2015a, 2015b), Lozza et al. (2018), Lu et al. (2018), Hoang et al. (2019), and Guo et al. (2020) to study different trading strategies. In addition, academics and practitioners could extend Liao and Liao and Wong (2008), Liao et al. (2012, 2014), Moslehpour et al. (2017), Moslehpour et al. (2018a, 2018b) to study marketing behavior; extend Moslehpour et al. (2018a) to study management behavior; extend Mou et al. (2018) and Pham et al. (2018) to study corporate behavior; and extend Thompson and Thompson and Wong (1991, 1996), Fung et al. (2011), Wong and Chan (2006), Xu et al. (2017), and Ly et al. (2019a, 2019b) to study the handling of risk. There is much other work studying behavior, investment, and trading strategy. Readers may refer to Chang et al. (2018) and Woo et al. (2020) for more information.

Author Contributions: Conceptualization, W.-K.W. and T.T.H.N.; writing—original draft preparation, T.T.H.N., and W.-K.W.; writing-review and editing, T.T.H.N., M.M., and W.-K.W.; supervision, W.-K.W.; analysing, T.T.H.N., and T.T.V.V.; formating, M.M., and T.T.V.V. All authors have read and agreed to the published version of the manuscript.

Funding: This research received no external funding.

Acknowledgments: The fourth author would also like to thank Robert B. Miller and Howard E. Thompson for their ongoing counseling and encouragement. Grants from Asia University, Saigon University, China Medical 
University Hospital, The Hang Seng University of Hong Kong, the Research Grants Council of Hong Kong (Project Number 12500915), and Ministry of Science and Technology (MOST, Project Numbers 106-2410-H-468-002 and 107-2410-H-468-002-MY3), Taiwan.

Conflicts of Interest: The authors declare no conflict of interest.

\section{References}

Abid, Fathi, Pui Leung, Mourad Mroua, and Wing Wong. 2014. International Diversification Versus Domestic Diversification: Mean-Variance Portfolio Optimization and Stochastic Dominance Approaches. Journal of Risk and Financial Management 7: 45-66. [CrossRef]

Abramov, Alexander, Alexander Radygin, Revold Entov, and Maria Chernova. 2017. State Ownership and Efficiency Characteristics. Russian Journal of Economics 3: 129-57. [CrossRef]

Ang, James S., David K. Ding, and Tiong Yang Thong. 2013. Political Connection and Firm Value. Asian Development Review 30: 131-66. [CrossRef]

Arellano, Manuel, and Stephen Bond. 1991. Some Tests of Specification for Panel Data: Monte Carlo Evidence and an Application to Employment Equations. The Review of Economic Studies 58: 277-97. [CrossRef]

Arellano, Manuel, and Olympia Bover. 1995. Another Look at the Instrumental Variable Estimation of Error-Components Models. Journal of Econometrics 68: 29-51. [CrossRef]

Ben-Nasr, Hamdi, Narjess Boubakri, and Jean Claude Cosset. 2015. Earnings Quality in Privatized Firms: The Role of State and Foreign Owners. Journal of Accounting and Public Policy 34: 392-416. [CrossRef]

Bhatti, Baqar Hussain, and Atiqa Sarwet. 2011. Financial Performance of State Owned Enterprises in Emerging Economies. Chartered Institute of Management Accountants 8: 1-14.

Blundell, Richard, Stephen Bond, and Frank Windmeijer. 2001. Estimation in Dynamic Panel Data Models: Improving on the Performance of the Standard Gmm Estimator. In Nonstationary Panels, Panel Cointegration, and Dynamic Panels. Edited by H. Baltagi Badi, B. Fomby Thomas and R. Carter Hill. Bingley: Emerald Group Publishing Limited, pp. 53-91.

Boubakri, Narjess, Omrane Guedhami, Dev Mishra, and Walid Saffar. 2012. Political Connections and the Cost of Equity Capital. Journal of Corporate Finance 18: 541-59. [CrossRef]

Boubakri, Narjess, Sattar A. Mansi, and Walid Saffar. 2013. Political Institutions, Connectedness, and Corporate Risk-Taking. Journal of International Business Studies 44: 195-215. [CrossRef]

Casciaro, Tiziana, and Mikolaj Jan Piskorski. 2005. Power Imbalance, Mutual Dependence, and Constraint Absorption: A Closer Look at Resource Dependence Theory. Administrative Science Quarterly 50: 167-99. [CrossRef]

Chan, Chia-Ying, Christian de Peretti, Zhuo Qiao, and Wing-Keung Wong. 2012. Empirical Test of the Efficiency of the Uk Covered Warrants Market: Stochastic Dominance and Likelihood Ratio Test Approach. Journal of Empirical Finance 19: 162-74. [CrossRef]

Chan, Raymond Hon Fu, Spike Tsz Ho Lee, and Wing-Keung Wong. 2014. Technical Analysis and Financial Asset Forecasting. Singapore: World Scientific.

Chan, Raymond Honfu, Sheung Chi Chow, Xu Guo, and Wing-Keung Wong. 2019. Central Moments, Stochastic Dominance, Moment Rule, and Diversification. Available online: https://ssrn.com/abstract=3431903 (accessed on 18 January 2020).

Chang, Chia-Lin, Michael McAleer, and Wing-Keung Wong. 2018. Big Data, Computational Science, Economics, Finance, Marketing, Management, and Psychology: Connections. Journal of Risk and Financial Management 11: 15. [CrossRef]

Chen, Yenn-Ru, and Yulong Ma. 2011. Revisiting the Risk-Taking Effect of Executive Stock Options on Firm Performance. Journal of Business Research 64: 640-48. [CrossRef]

Chen, Victor Zitan, Jing Li, Daniel M. Shapiro, and Xiaoxiang Zhang. 2013. Ownership Structure and Innovation: An Emerging Market Perspective. Asia Pacific Journal of Management 31: 1-24. [CrossRef]

Cheng, Teng Yuan, Chun I. Lee, and Chao Hsien Lin. 2020. The Effect of Risk-Taking Behavior on Profitability: Evidence from Futures Market. Economic Modelling 86: 19-38. [CrossRef]

Chiang, Thomas, Hooi Hooi Lean, and Wing-Keung Wong. 2008. Do Reits Outperform Stocks and Fixed-Income Assets? New Evidence from Mean-Variance and Stochastic Dominance Approaches. Journal of Risk and Financial Management 1: 1-40. [CrossRef] 
Chong, Lee-Lee, Hway-Boon Ong, and Siow-Hooi Tan. 2018. Corporate Risk-Taking and Performance in Malaysia: The Effect of Board Composition, Political Connections and Sustainability Practices. Corporate Governance: The International Journal of Business in Society. [CrossRef]

Clark, Ephraim, Zhuo Qiao, and Wing-Keung Wong. 2015. Theories of Risk: Testing Investor Behavior on the Taiwan Stock and Stock Index Futures Markets. Economic Inquiry 54: 907-24. [CrossRef]

De la Torre, Augusto, Juan Carlos Gozzi, and Sergio L. Schmukler. 2007. Stock Market Development under Globalization: Whither the Gains from Reforms? Journal of Banking \& Finance 31: 1731-54. [CrossRef]

Díez-Esteban, José María, Conrado Diego García-Gómez, Félix Javier López-Iturriaga, and Marcos Santamaría-Mariscal. 2017. Corporate Risk-Taking, Returns and the Nature of Major Shareholders: Evidence from Prospect Theory. Research in International Business and Finance 42: 900-11. [CrossRef]

Durnev, Art, Kan Li, Randall Morck, and Bernard Yeung. 2004. Capital Markets and Capital Allocation: Implications for Economies in Transition. The Economics of Transition 12: 593-634. [CrossRef]

Egozcue, Martin, and Wing-Keung Wong. 2010. Gains from Diversification on Convex Combinations: A Majorization and Stochastic Dominance Approach. European Journal of Operational Research 200: 893-900. [CrossRef]

Egozcue, Martín, Luis Fuentes García, Wing-Keung Wong, and Ričardas Zitikis. 2011. Do Investors Like to Diversify? A Study of Markowitz Preferences. European Journal of Operational Research 215: 188-93. [CrossRef]

Egozcue, Martín, Xu Guo, and Wing-Keung Wong. 2015. Optimal Output for the Regret-Averse Competitive Firm under Price Uncertainty. Eurasian Economic Review 5: 279-95. [CrossRef]

Fabozzi, Frank J., Chun-Yip Fung, Kin Lam, and Wing-Keung Wong. 2013. Market Overreaction and Underreaction: Tests of the Directional and Magnitude Effects. Applied Financial Economics 23: 1469-82. [CrossRef]

Faccio, Mara. 2010. Differences between Politically Connected and Nonconnected Firms: A Cross-Country Analysis. Financial Management 39: 905-28. [CrossRef]

Faccio, Mara, Ronald W. Masulis, and John J. McConnell. 2006. Political Connections and Corporate Bailouts. The Journal of Finance 61: 2597-635. [CrossRef]

Faccio, Mara, Maria-Teresa Marchica, and Roberto Mura. 2011. Large Shareholder Diversification and Corporate Risk-Taking. Review of Financial Studies 24: 3601-41. [CrossRef]

Faccio, Mara, Maria-Teresa Marchica, and Roberto Mura. 2016. Ceo Gender, Corporate Risk-Taking, and the Efficiency of Capital Allocation. Journal of Corporate Finance 39: 193-209. [CrossRef]

Fan, Joseph, T. Wong, and Tianyu Zhang. 2007. Politically Connected Ceos, Corporate Governance, and Post-Ipo Performance of China's Newly Partially Privatized Firms 次. Journal of Financial Economics 84: 330-57. [CrossRef]

Farag, Hisham, and Chris Mallin. 2016. The Influence of Ceo Demographic Characteristics on Corporate Risk-Taking: Evidence from Chinese Ipos. The European Journal of Finance 24: 1528-51. [CrossRef]

Fogel, Kathy, Randall Morck, and Bernard Yeung. 2008. Big Business Stability and Economic Growth: Is What's Good for General Motors Good for America? Journal of Financial Economics 89: 83-108. [CrossRef]

Friedman, Milton. 1962. Capitalism and Freedom. Chicago: University of Chicago Press.

Frugier, Alain. 2016. Returns, Volatility and Investor Sentiment: Evidence from European Stock Markets. Research in International Business and Finance 38: 45-55. [CrossRef]

Frynas, Jędrzej George, Kamel Mellahi, and Geoffrey Allen Pigman. 2006. First Mover Advantages in International Business and Firm-Specific Political Resources. Strategic Management Journal 27: 321-45. [CrossRef]

Fung, Eric, Kin Lam, Tak-Kuen Siu, and Wing-Keung Wong. 2011. A Pseudo-Bayesian Model for Stock Returns in Financial Crises. Journal of Risk and Financial Management 4: 43-73. [CrossRef]

Gillette, Ann B., Thomas H. Noe, and Michael J. Rebello. 2003. Corporate Board Composition, Protocols, and Voting Behavior: Experimental Evidence. Journal of Finance 58: 1997-2031. [CrossRef]

Guo, Xu, and Wing-Keung Wong. 2019. Comparison of the Production Behavior of Regret-Averse and Purely Risk-Averse Firms. Estudios de Economía 46: 157-61. [CrossRef]

Guo, Xu, Xuejun Jiang, and Wing-Keung Wong. 2017a. Stochastic Dominance and Omega Ratio: Measures to Examine Market Efficiency, Arbitrage Opportunity, and Anomaly. Economies 5: 38. [CrossRef]

Guo, Xu, Michael McAleer, Wing-Keung Wong, and Lixing Zhu. 2017b. A Bayesian Approach to Excess Volatility, Short-Term Underreaction and Long-Term Overreaction During Financial Crises. The North American Journal of Economics and Finance 42: 346-58. [CrossRef] 
Guo, Xu, Martín Egozcue, and Wing Keung Wong. 2020. Production Theory under Price Uncertainty for Firms with Disappointment Aversion. International Journal of Production Research, 1-14. [CrossRef]

Hillman, Amy J., Asghar Zardkoohi, and Leonard Bierman. 1999. Corporate Political Strategies and Firm Performance: Indications of Firm-Specific Benefits from Personal Service in the U.S. Government. Strategic Management Journal 20: 67-81. [CrossRef]

Hoang, Thi-Hong-Van, Hooi Hooi Lean, and Wing-Keung Wong. 2015a. Is Gold Good for Portfolio Diversification? A Stochastic Dominance Analysis of the Paris Stock Exchange. International Review of Financial Analysis 42: 98-108. [CrossRef]

Hoang, Thi-Hong-Van, Wing-Keung Wong, and Zhenzhen Zhu. 2015b. Is Gold Different for Risk-Averse and Risk-Seeking Investors? An Empirical Analysis of the Shanghai Gold Exchange. Economic Modelling 50: 200-11. [CrossRef]

Hoang, Thi-Hong-Van, Zhenzhen Zhu, Abdelbari El Khamlichi, and Wing-Keung Wong. 2019. Does the Shari'ah Screening Impact the Gold-Stock Nexus? A Sectorial Analysis. Resources Policy 61: 617-26. [CrossRef]

Hope, Ole-Kristian. 2013. Large Shareholders and Accounting Research. China Journal of Accounting Research 6: 3-20. [CrossRef]

Hoskisson, Robert E., Francesco Chirico, Jinyong Zyung, and Eni Gambeta. 2016. Managerial Risk Taking: A Multitheoretical Review and Future Research Agenda. Journal of Management 43: 137-69. [CrossRef]

Jensen, Michael C., and William H. Meckling. 1976. Theory of the Firm: Managerial Behavior, Agency Costs and Ownership Structure. Journal of Financial Economics 3: 305-60. [CrossRef]

Kahneman, Daniel, and Amos Tversky. 1979. Prospect Theory: An Analysis of Decision under Risk. Econometrica 47: 263. [CrossRef]

Kang, Young-sam, and Byung-yeon Kim. 2012. Ownership Structure and Firm Performance: Evidence from the Chinese Corporate Reform. China Economic Review 23: 471-81. [CrossRef]

Khan, Farman, Junrui Zhang, Muhammad Usman, Alina Badulescu, and Muhammad Sial. 2019. Ownership Reduction in State-Owned Enterprises and Corporate Social Responsibility: Perspective from Secondary Privatization in China. Sustainability 11: 1008. [CrossRef]

Khaw, Karren Lee-Hwei, Jing Liao, David Tripe, and Udomsak Wongchoti. 2016. Gender Diversity, State Control, and Corporate Risk-Taking: Evidence from China. Pacific-Basin Finance Journal 39: 141-58. [CrossRef]

Khuong, Nguyen Vinh, Nguyen Tran Thai Ha, Mai Thi Hoang Minh, and Phung Anh Thu. 2019. Does Corporate Tax Avoidance Explain Cash Holdings? The Case of Vietnam. Economics E Sociology 12: 79-93. [CrossRef]

Kogan, Nathan, and Michael A. Wallach. 1964. Risk-Taking: A Study in Cognition and Personality. New York: Holt. Kraus, Sascha, J. P. Coen Rigtering, Mathew Hughes, and Vincent Hosman. 2011. Entrepreneurial Orientation and the Business Performance of Smes: A Quantitative Study from the Netherlands. Review of Managerial Science 6: 161-82. [CrossRef]

Kung, James J., and Wing-Keung Wong. 2009a. Efficiency of the Taiwan Stock Market. Japanese Economic Review 60: 389-94. [CrossRef]

Kung, James J., and Wing-Keung Wong. 2009b. Profitability of Technical Analysis in the Singapore Stock Market: Before and after the Asian Financial Crisis. Journal of Economic Integration 24: 135-50. [CrossRef]

Lam, Vincent Wing-Shing, Terence Tai-Leung Chong, and Wing-Keung Wong. 2007. Profitability of Intraday and Interday Momentum Strategies. Applied Economics Letters 14: 1103-8. [CrossRef]

Lam, Kin, Taisheng Liu, and Wing-Keung Wong. 2010. A Pseudo-Bayesian Model in Financial Decision Making with Implications to Market Volatility, under- and Overreaction. European Journal of Operational Research 203: 166-75. [CrossRef]

Lam, Kin, Taisheng Liu, and Wing-Keung Wong. 2012. A New Pseudo-Bayesian Model with Implications for Financial Anomalies and Investors' Behavior. Journal of Behavioral Finance 13: 93-107. [CrossRef]

Lean, Hooi Hooi, Russell Smyth, and Wing-Keung Wong. 2007. Revisiting Calendar Anomalies in Asian Stock Markets Using a Stochastic Dominance Approach. Journal of Multinational Financial Management 17: 125-41. [CrossRef]

Lean, Hooi Hooi, Michael McAleer, and Wing-Keung Wong. 2010. Market Efficiency of Oil Spot and Futures: A Mean-Variance and Stochastic Dominance Approach. Energy Economics 32: 979-86. [CrossRef]

Lean, Hooi Hooi, Kok Fai Phoon, and Wing-Keung Wong. 2012. Stochastic Dominance Analysis of Cta Funds. Review of Quantitative Finance and Accounting 40: 155-70. [CrossRef] 
Li, Jinxian, and Xiaojian Liu. 2017. Trust Beneficiary Protection, Ownership Structure, and Risk Taking of Trust Corporations: Evidence from China. Emerging Markets Finance and Trade 53: 1318-36. [CrossRef]

Li, Chi-Kwong, and Wing-Keung Wong. 1999. Extension of Stochastic Dominance Theory to Random Variables. RAIRO-Operations Research 33: 509-24. [CrossRef]

Li, Zongxin, Xinge Li, Yongchang Hui, and Wing-Keung Wong. 2018. Maslow Portfolio Selection for Individuals with Low Financial Sustainability. Sustainability 10: 1128. [CrossRef]

Liao, Z., and W. K. Wong. 2008. The Determinants of Customer Interactions with Internet-Enabled E-Banking Services. Journal of the Operational Research Society 59: 1201-10. [CrossRef]

Liao, Ziqi, Xinping Shi, and Wing-Keung Wong. 2012. Consumer Perceptions of the Smartcard in Retailing: An Empirical Study. Journal of International Consumer Marketing 24: 252-62. [CrossRef]

Liao, Ziqi, Xinping Shi, and Wing-Keung Wong. 2014. Key Determinants of Sustainable Smartcard Payment. Journal of Retailing and Consumer Services 21: 306-13. [CrossRef]

Lin, Chen, Yue Ma, and Dongwei Su. 2009. Corporate Governance and Firm Efficiency: Evidence from China's Publicly Listed Firms. Managerial and Decision Economics 30: 193-209. [CrossRef]

Lin, Woon-Leong, Jun-Hwa Cheah, Mohamed Azali, Jo Ann Ho, and Nick Yip. 2019. Does Firm Size Matter? Evidence on the Impact of the Green Innovation Strategy on Corporate Financial Performance in the Automotive Sector. Journal of Cleaner Production 229: 974-88. [CrossRef]

Ling, Leng, Xiaorong Zhou, Quanxi Liang, Pingping Song, and Haijian Zeng. 2016. Political Connections, Overinvestments and Firm Performance: Evidence from Chinese Listed Real Estate Firms. Finance Research Letters 18: 328-33. [CrossRef]

Lozza, Ortobelli Sergio, Wing-Keung Wong, Frank J. Fabozzi, and Martin Egozcue. 2018. Diversification Versus Optimality: Is There Really a Diversification Puzzle? Applied Economics 50: 4671-93. [CrossRef]

Lu, Richard, Chen-Chen Yang, and Wing-Keung Wong. 2018. Time Diversification: Perspectives from the Economic Index of Riskiness. Annals of Financial Economics 13: 1850011. [CrossRef]

Luo, Danglun, Kevin C. W. Chen, and Lifan Wu. 2017. Political Uncertainty and Firm Risk in China. Review of Development Finance 7: 85-94. [CrossRef]

Lux, Sean, T. Russell Crook, and David J. Woehr. 2010. Mixing Business with Politics: A Meta-Analysis of the Antecedents and Outcomes of Corporate Political Activity. Journal of Management 37: 223-47. [CrossRef]

Ly, Sel, Kim-Hung Pho, Sal Ly, and Wing-Keung Wong. 2019a. Determining Distribution for the Quotients of Dependent and Independent Random Variables by Using Copulas. Journal of Risk and Financial Management 12: 42. [CrossRef]

Ly, Sel, Kim-Hung Pho, Sal Ly, and Wing-Keung Wong. 2019b. Determining Distribution for the Product of Random Variables by Using Copulas. Risks 7: 23. [CrossRef]

Mishra, Dev R. 2011. Multiple Large Shareholders and Corporate Risk Taking: Evidence from East Asia. Corporate Governance: An International Review 19: 507-28. [CrossRef]

Moslehpour, Massoud, Wing-Keung Wong, Yi Hsin Lin, and Thi Le Huyen Nguyen. 2017. Top Purchase Intention Priorities of Vietnamese Low Cost Carrier Passengers: Expectations and Satisfaction. Eurasian Business Review 8: 371-89. [CrossRef]

Moslehpour, Massoud, Van Pham, Wing-Keung Wong, and İsmail Bilgiçli. 2018a. E-Purchase Intention of Taiwanese Consumers: Sustainable Mediation of Perceived Usefulness and Perceived Ease of Use. Sustainability 10: 234. [CrossRef]

Moslehpour, Massoud, Wing-Keung Wong, Van Kien Pham, and Carrine K. Aulia. 2018b. Repurchase Intention of Korean Beauty Products among Taiwanese Consumers. SSRN Electronic Journal. [CrossRef]

Mou, WeiMing, Wing-Keung Wong, and Michael McAleer. 2018. Financial Credit Risk Evaluation Based on Core Enterprise Supply Chains. Sustainability 10: 3699. [CrossRef]

Mun, Sung Gyun, and SooCheong Jang. 2015. Working Capital, Cash Holding, and Profitability of Restaurant Firms. International Journal of Hospitality Management 48: 1-11. [CrossRef]

Munkh-Ulzii, Batmunkh, Michael McAleer, Massoud Moslehpour, and Wing-Keung Wong. 2018. Confucius and Herding Behaviour in the Stock Markets in China and Taiwan. Sustainability 10: 4413. [CrossRef]

Najid, Nurul Afzan, and Rashidah Abdul Rahman. 2011. Government Ownership and Performance of Malaysian Government-Linked Companies. International Research Journal of Finance and Economics 61: 42-56. 
Nguyen, Thang V., Ngoc T. B. Le, and Scott E. Bryant. 2013. Sub-National Institutions, Firm Strategies, and Firm Performance: A Multilevel Study of Private Manufacturing Firms in Vietnam. Journal of World Business 48: 68-76. [CrossRef]

Nguyen, Tran Thai Ha, Thi Thuy Van Vo, Anh Thu Phung, and Thi Hong Anh Le. 2019. Institutional Environment, Government Ownership and Firm Profitability: Empirical Evidence from Vietnam. Academy of Accounting and Financial Studies Journal 23: 1-11.

Nobre, Liana Holanda Nepomuceno, John E. Grable, Wesley Vieira da Silva, and Fábio Chaves Nobre. 2018. Managerial Risk Taking: A Conceptual Model for Business Use. Management Decision 56: 2487-501. [CrossRef]

Pfeffer, J., and G. R. Salancik. 1978. The External Control of Organizations: A Resource Dependence Perspective. Academy of Management Review 4: 521-32.

Pham, Van Kien, Wing-Keung Wong, Massoud Moslehpour, and Dennis Musyoki. 2018. Simultaneous Adaptation of Ahp and Fuzzy Ahp to Evaluate Outsourcing Service in East and Southeast Asia. Journal of Testing and Evaluation 48: 20170420. [CrossRef]

Phung, Duc Nam, and Anil V. Mishra. 2015. Ownership Structure and Firm Performance: Evidence from Vietnamese Listed Firms. Australian Economic Papers 55: 63-98. [CrossRef]

Pratt, John W. 1964. Risk Aversion in the Small and in the Large. Econometrica 32: 122. [CrossRef]

Qiao, Zhuo, and Wing-Keung Wong. 2015. Which Is a Better Investment Choice in the Hong Kong Residential Property Market: A Big or Small Property? Applied Economics 47: 1670-85. [CrossRef]

Qiao, Zhuo, Ephraim Clark, and Wing-Keung Wong. 2012. Investors' Preference Towards Risk: Evidence from the Taiwan Stock and Stock Index Futures Markets. Accounting \& Finance 54: 251-74. [CrossRef]

Qiao, Zhuo, Wing-Keung Wong, and Joseph K. W. Fung. 2013. Stochastic Dominance Relationships between Stock and Stock Index Futures Markets: International Evidence. Economic Modelling 33: 552-59. [CrossRef]

Quang, Do Xuan, and Wu Zhong Xin. 2014. The Impact of Ownership Structure and Capital Structure on Financial Performance of Vietnamese Firms. International Business Research 7. [CrossRef]

Roodman, David. 2009. How to Do Xtabond2: An Introduction to Difference and System Gmm in Stata. The Stata Journal 9: 86-136. [CrossRef]

Santos, Filipe M., and Kathleen M. Eisenhardt. 2005. Organizational Boundaries and Theories of Organization. Organization Science 16: 491-508. [CrossRef]

Schweizer, Denis, Thomas Walker, and Aoran Zhang. 2019. Cross-Border Acquisitions by Chinese Enterprises: The Benefits and Disadvantages of Political Connections. Journal of Corporate Finance 57: 63-85. [CrossRef]

Sharma, Piyush, Louis T. W. Cheng, and Tak Yan Leung. 2020. Impact of Political Connections on Chinese Export Firms' Performance-Lessons for Other Emerging Markets. Journal of Business Research 106: 24-34. [CrossRef]

Shoham, Aviv, and Avi Fiegenbaum. 2002. Competitive Determinants of Organizational Risk-Taking Attitude: The Role of Strategic Reference Points. Management Decision 40: 127-41. [CrossRef]

Slovic, Paul. 1964. Assessment of Risk Taking Behavior. Psychological Bulletin 61: 220-33. [CrossRef]

Song, Zengji, Abraham Nahm, and Jun Yang. 2016. Institutional Environment, Political Connections of Partial State Ownership, and Performance. International Journal of Social Economics 43: 856-70. [CrossRef]

Stulz, René M. 2015. Risk-Taking and Risk Management by Banks. Journal of Applied Corporate Finance 27: 8-18. [CrossRef]

Su, Kun, Liuchuang Li, and Rui Wan. 2016. Ultimate Ownership, Risk-Taking and Firm Value: Evidence from China. Asia Pacific Business Review 23: 10-26. [CrossRef]

Sun, Pei, Kamel Mellahi, and Mike Wright. 2012. The Contingent Value of Corporate Political Ties. Academy of Management Perspectives 26: 68-82. [CrossRef]

Sur, Sujit, Elena Lvina, and Michel Magnan. 2013. Why Do Boards Differ? Because Owners Do: Assessing Ownership Impact on Board Composition. Corporate Governance: An International Review 21: 373-89. [CrossRef]

Thanh, Su Dinh, Nguyen Phuc Canh, and Nguyen Tran Thai Ha. 2019. Debt Structure and Earnings Management: A Non-Linear Analysis from an Emerging Economy. Finance Research Letters. [CrossRef]

Thompson, Howard E., and Wing K. Wong. 1991. On the Unavoidability of 'Unscientific' Judgment in Estimating the Cost of Capital. Managerial and Decision Economics 12: 27-42. [CrossRef]

Thompson, Howard E., and Wing-Keung Wong. 1996. Revisiting "Dividend Yield Plus Growth" and Its Application. The Engineering Economist 41: 123-47. [CrossRef]

Tobin, J. 1958. Liquidity Preference as Behavior Towards Risk. The Review of Economic Studies 25: 65. [CrossRef] 
Tsang, Chun-Kei, Wing-Keung Wong, and Ira Horowitz. 2016. Arbitrage Opportunities, Efficiency, and the Role of Risk Preferences in the Hong Kong Property Market. Studies in Economics and Finance 33: 735-54. [CrossRef] Uddin, Md Hamid. 2016. Effect of Government Share Ownership on Corporate Risk Taking: Case of the United Arab Emirates. Research in International Business and Finance 36: 322-39. [CrossRef]

Van Thang, Nguyen, and Nick J. Freeman. 2009. State-Owned Enterprises in Vietnam: Are They 'Crowding out' the Private Sector? Post-Communist Economies 21: 227-47. [CrossRef]

Vereshchagina, Galina, and Hugo A. Hopenhayn. 2009. Risk Taking by Entrepreneurs. American Economic Review 99: 1808-30. [CrossRef]

Vo, Xuan Vinh. 2018. Do Firms with State Ownership in Transitional Economies Take More Risk? Evidence from Vietnam. Research in International Business and Finance 46: 251-56. [CrossRef]

Wang, Q., T. J. Wong, and L. Xia. 2008. State Ownership, the Institutional Environment, and Auditor Choice: Evidence from China. Journal of Accounting and Economics 46: 112-34. [CrossRef]

Wong, Wing-Keung. 2006. Stochastic Dominance Theory for Location-Scale Family. Journal of Applied Mathematics and Decision Sciences 2006: 1-10. [CrossRef]

Wong, Wing-Keung. 2007. Stochastic Dominance and Mean-Variance Measures of Profit and Loss for Business Planning and Investment. European Journal of Operational Research 182: 829-43. [CrossRef]

Wong, Wing-Keung, and Raymond H. Chan. 2006. On the Estimation of Cost of Capital and Its Reliability. Quantitative Finance 4: 365-72. [CrossRef]

Wong, Wing-Keung, and Raymond H. Chan. 2008. Prospect and Markowitz Stochastic Dominance. Annals of Finance 4: 105-29. [CrossRef]

Wong, Wing-Keung, and Chi-Kwong Li. 1999. A Note on Convex Stochastic Dominance. Economics Letters 62: 293-300. [CrossRef]

Wong, Wing-Keung, and Chenghu Ma. 2007. Preferences over Location-Scale Family. Economic Theory 37: 119-46. [CrossRef]

Wong, Wing-Keung, and Zhuo Qiao. 2020. Why Investors Buy Insurance and Try Their Luck with Lotteries as Well? Available online: https://ssrn.com/abstract=2980007 (accessed on 18 January 2020).

Wong, Wing-Keung, Boon-Kiat Chew, and Douglas Sikorsk. 2001. Can the Forecasts Generated from E/P Ratio and Bond Yield Be Used to Beat Stock Markets? Multinational Finance Journal 5: 59-86. [CrossRef]

Wong, Wing-Keung, Meher Manzur, and Boon-Kiat Chew. 2003. How Rewarding Is Technical Analysis? Evidence from Singapore Stock Market. Applied Financial Economics 13: 543-51. [CrossRef]

Wong, Wing-Keung, Kok Fai Phoon, and Hooi Hooi Lean. 2008. Stochastic Dominance Analysis of Asian Hedge Funds. Pacific-Basin Finance Journal 16: 204-23. [CrossRef]

Wong, Wing-Keung, Hooi Lean, Michael McAleer, and Feng-Tse Tsai. 2018. Why Are Warrant Markets Sustained in Taiwan but Not in China? Sustainability 10: 3748. [CrossRef]

Woo, Kai-Yin, Chulin Mai, Michael McAleer, and Wing-Keung Wong. 2020. Review on Efficiency and Anomalies in Stock Markets. Economies 8: 20. [CrossRef]

$\mathrm{Xu}$, Ronghua, Wing-Keung Wong, Guanrong Chen, and Shuo Huang. 2017. Topological Characteristics of the Hong Kong Stock Market: A Test-Based P-Threshold Approach to Understanding Network Complexity. Scientific Reports 7: 41379-79. [CrossRef] [PubMed]

Younas, Zahid Irhsad, and Ameena Zafar. 2019. Corporate Risk Taking and Sustainability: A Case of Listed Firms from USA and Germany. Journal of Global Responsibility 10: 2-15. [CrossRef]

Young, Michael N., Terence Tsai, Xinran Wang, Shubo Liu, and David Ahlstrom. 2014. Strategy in Emerging Economies and the Theory of the Firm. Asia Pacific Journal of Management 31: 331-54. [CrossRef]

Zhai, Shengbao, Lu Xie, and Sheng Zhang. 2015. Bank Connections and Corporate Risk-Taking: Evidence from China. Asia-Pacific Journal of Accounting \& Economics 24: 183-94. [CrossRef]

Zhou, Kevin Zheng, Gerald Yong Gao, and Hongxin Zhao. 2016. State Ownership and Firm Innovation in China: An Integrated View of Institutional and Efficiency Logics. Administrative Science Quarterly 62: 375-404. [CrossRef]

(C) 2020 by the authors. Licensee MDPI, Basel, Switzerland. This article is an open access article distributed under the terms and conditions of the Creative Commons Attribution (CC BY) license (http://creativecommons.org/licenses/by/4.0/). 